IRSH 46 (200I), pp. 37I-39I DOI: I0.1017/S0020859001000244

(C) 200 I Internationaal Instituut voor Sociale Geschiedenis

\title{
Conflict Across the Atlantic: Women, Family and Mass Male Migration in Sicily, I880-1920*
}

\author{
LIN D A REE DER
}

SUmmary: This article looks at the effect of transoceanic migration on rural Sicilian families. The author focuses on the conflicts, stresses, and transformations experienced by members of transnational families. While the reality of migration rarely reflected the popular notion that emigration would ruin families, the experience did create deep divisions between migrant men and the women who remained behind. Even before men migrated, husbands and wives struggled over the initial decision to emigrate. From their differing positions within the family, men and women separately weighed the potential benefits and risks of migration. When women encouraged their husbands to work overseas, the experience of migration often created new dreams and opportunities that divided family members. This essay highlights the deeply gendered nature of transnational migration, and the role of the family in altering ideas of husband, wife, mother, and father.

In the fall of 1909 , Giuseppa T, pregnant with her first child, bid farewell to her husband Carmelo M. He left Sutera, a small hill town in western Sicily, to work in the coal mines near Birmingham, Alabama. For a while, all went well. Carmelo quickly found work and sent money home on a regular basis. In I9I 3, the remittances stopped. For two long years Giuseppa heard nothing from Carmelo, and finally she asked the mayor to contact the Italian consulate in Alabama to find her missing husband. Within a few weeks, Giuseppa received a reply from the consulate. Carmelo testified that for the past three months he had been ill and unemployed and unable to send his wife anything, though he offered no excuse for the preceding twenty-one months. He promised he would resume payments as soon as possible. Toward the end of the interview, Carmelo insisted that the consular officer put in writing how,

\footnotetext{
* Earlier versions of this article were presented at the Social Science History Conference, November 1999, and at the International Social Science History Conference, April I 999. I would like to thank Donna Gabaccia, Wendy Gordon, Theodore Koditschek, Marlou Schrover and David Tager for their insightful comments. I would also like to thank two reviewers for their excellent suggestions.
} 
[...] for the past three years or so he had sent his wife a prepaid ticket from Palermo to Birmingham for herself and their seven-year-old daughter. Each year she returned the ticket, telling him she would never cross the Atlantic to join him, and that if he wanted to see his family he had to come home to Sutera. Furthermore, he stated, that while he was still willing to bring his family to the United States, he, himself, would never return to Sicily. ${ }^{\mathrm{I}}$

Giuseppa never left Sutera and Carmelo never came home.

The story of Giuseppa and Carmelo is an extreme example of the difficulties so many people experienced when families stretched across the ocean. Between I 880 and I9I4 over a million Sicilians, mostly men, left their island homes. ${ }^{2}$ In most cases, migrant men and their wives back home managed to resolve the conflicting desires that destroyed Giuseppa's and Carmelo's marriage. Although exceptional, the story of this ill-fated couple is important. Their story resonated in a world where emigration was seen as an enemy of the family. The idea that emigration destroyed the family was prevalent in serialized fiction, newspaper articles, and political discussions. Even in small-town Sicily, where migration rarely divided families, the issues that Giuseppa and Carmelo grappled with were the same ones that most transnational families faced. Transoceanic migration heightened the conflicting interests of men and women that characterized these family economies, where men earned wages and women managed the household. From conflicts over the initial decision to leave, to the family's eventual reunification, relocation, or dissolution, husbands and wives struggled over the meaning of migration for the family. Once men found work in the Americas and sent money and gifts home to their families, struggles ensued over the control of these new sources of wealth. In the wake of mass migration, as men and women sought to redefine their economic and social roles in relation to each other and the wider world, the family itself became a site of negotiation, accommodation, and conflict.

The recognition that mass migration transformed family relations builds on the work of numerous scholars in a variety of fields. Historians of the family have moved from demographic studies and family reconstructions designed to study how families worked, to studies seeking to understand the changing nature of family dynamics. Recent work has emphasized the fluidity of family, seeing the institution as a flexible and ever-changing system of kin-relations whose boundaries expand and contrast in time with economic, social, and cultural changes. Historians of women enthusiastically embraced the idea that family was inextricably linked to systems of production and consumption. Although women rarely figured

I. Archivio Comunale di Sutera [hereafter, ACS], "Memo: dal R. Agenzia Consolare d'Italia Birmingham, Alabama al Sindaco di Sutera, 7 Dicembre 1915", no. 2179 , cat. I3, cl. I, fasc. I. 2. Ministero degli Affari Esteri [hereafter, MAE], Annuario statistica della emigrazione italiana I876-1925 (Rome, I927), p. I83. 
in traditional historical events, they did play a central role in the family economy. The transformation of the family from a place of production to a wage-earning collective oriented toward consumption quickly became an accepted premise in the field. ${ }^{3}$

The close relationship between women's history and family history has been extremely fruitful at both an empirical and a theoretical level; however, it is important to remember that the fields are not the same. The family is not an exclusively female world. As a site where production, consumption, and reproduction merge, the family is a deeply gendered place. The south Italian family, like the working-class household in England, was physically, socially, and emotionally divided by gender. The "father's chair" and the "mother's loom" reflected more than mere ownership. Naming practices reveal a sharp division of labor and power. In the most harmonious households, the interests of husbands, wives, and children coincided, and their roles as providers and managers complimented one another. But most families experienced dissension when wages were insufficient to put food on the table. Unemployment, disability, or illness disrupted the family economy and heightened tensions between husbands and wives as the women sought to perform their household duties on a dwindling income. ${ }^{4}$ The sexual division of labor that characterized nineteenth-century families is one way to understand gender roles in the family; however, it would be misleading to see the family as just a place where the distinct worlds of men and women collide. The family also produced public and private ideas of male, female, mother, father, husband, and wife.

These new insights into the multiple meanings of family can help us understand the experience of transnational migration. Scholars of migration have long recognized that family is a central organizing principle in Italian migration. Over the past three decades, historians have accepted as gospel the idea that kinship ties shaped migrant networks, patterns of work, settlement, and assimilation: brothers followed brothers, sons followed fathers, and nephews followed uncles. The family provided the basis for identity in the old world and in the new one. More recently, historians of women have used the family to write the history of female migrants, uncovering the particular experiences of women who, with a few

3. Tamara K. Hareven, Families, History, and Social Change: Life-Course and Cross-Cultural Perspectives (Boulder, CO, 2000), pp. 3-30; Louise A. Tilly and Joan W. Scott, Women, Work and Family (London [etc.], 1989); Deborah Simonton, A History of Women's Work: 1700 to the Present (London [etc.], 1998); for the Italian family, see David Kertzer The Family in Italy: From Antiquity to the Present (New Haven, CT, 199I).

4. Franca Iacovetta, "Making 'New Canadians': Social Workers, Women and the Reshaping of Immigrant Families", in Franca Iacovetta and Mariana Valverde (eds), Gender Conflicts: New Essays in Women's History (Toronto, 1992), pp. 261-303, 265; see also Ellen Ross, Love and Toil: Motherhood in Outcast London, I870-1918 (New York [etc.], I993), pp. 30-90. 
notable exceptions (the Irish and more recent Caribbean migrants), migrated as family members, rather than as independent laborers. Although they constructed and used kin networks in different ways, newly arrived emigrants (male and female) relied on family to help find housing and work, and to ease their homesickness. ${ }^{5}$

Scholars of the Italian immigrant experience in North America usually focus their work on families who settled in North America, and have rarely considered the transnational family. These studies have been critical in highlighting the importance of gender and class in the process of assimilation, settlement, and ethnic formation, but by focusing on the immigrant family they tend to assume that migration did not wreck the original family. Historical evidence seems to support this conclusion. In his introduction to the Sola family letters, Samuel Baily recounted how the Sola brothers, living in Argentina, continued to support their aging parents. Baily writes, "No one imagined the emigration and separation would provoke any tear in the web of family relations. And they were right." 6 Looking at the experiences of the Sola family, it is true, there was no visible tear. The brothers established their families on one side of the Atlantic, never losing touch with their parents back home. Yet, while many families were not torn apart, many found that migration experience placed a tremendous strain on the family and altered family relations. As historian Robert Harney wrote, "a tradition of happy endings has grown up to obscure the disruption and pain caused by long sojourning abroad". 7 Robert Harney, who was among the first migration scholars to see the migrant family in a transnational context, acknowledged that emigration placed "extraordinary stress" on migrant men and their families. These "men without women" worried about their wives, children and aging parents. Could they make enough money to fulfill their obligations as husbands and sons? Could they continue to protect their families' honor and status? Would their wives remain faithful? A man's prolonged absence could jeopardize a family's social position and economic wellbeing. Harney's article raises a host of fascinating questions regarding the ability of male migrants to realize emigrant dreams. However, as Harney notes,

5. Some of the earliest works discussing the family are Rudolph J. Vecoli, "Contadini in Chicago: A Critique of the Uprooted", The Journal of American History, 5 I (1964), pp. 404-4I 7; for more recent works see Virginia Yans-McLaughlin, "Introduction", in idem (ed), Immigration Reconsidered (New York [etc.], 1990), pp. 3- I 8; Barbara H. Settles et. al., Families on the Move: Migration, Immigration, Emigration, and Mobility (New York, [etc.], 1993); Donna Gabaccia, From the Other Side: Women, Gender, and Immigrant Life in the US 1820-1990 (Bloomington, IN [etc.], I994), pp. I3-41, 61-76.

6. Samuel Baily and Franco Remella (eds), One Family, Two Worlds: An Italian Family's Correspondence Across the Atlantic, I90I-I922 (New Brunswick, NJ , I988), p. I 3.

7. Robert F. Harney, "Men Without Women: Italian Migrants in Canada, I885-1930", in Betty Boyd Caroli, Robert F. Harney, and Lydio F. Tomasi (eds), The Italian Immigrant Woman of North America (Toronto, I978), pp. 79-10г. 
the decision to emigrate was a family one, and the goals and desires of the women who remained behind informed many of the choices made by male migrants.

Shifting our attention to the homeland, and in particular to the women who remained behind, deepens our understanding of the relationship between migration and the family. From the perspective of late nineteenthcentury Italy, few people questioned the notion that transatlantic migration would ravage family ties. Contrary to the expectations of emigrants, contemporary writers, journalists, and politicians generally agreed that prolonged separation would end in prostitution, destitution, insanity, or worse. A close examination of these lurid stories of betrayal, madness, and poverty, in light of the economic, social, and political changes that altered the role of husband, wife, parent, and child, reveals the conflict and tensions faced by the transnational family.

\section{ABANDONED WIVES AND WANTON WOMEN}

In early February of 1908, a short item entitled "The dramas of an adulterer" appeared in the Giornale di Sicilia. On the evening of I February 1908, Carmelo Savoca left his home with his rifle in his hand to murder Mariano di Bella. Carmelo had recently returned home from America and found his family in a shambles. In his absence, his wife had taken up with the young Mariano and soon found herself pregnant. The baby died, and Savoca's wife was convicted of infanticide. Seeking to avenge his honor, and perhaps lessen his grief, Carmelo killed the young Mariano and turned himself in to the authorities. ${ }^{8}$ Stories of these cuckolded migrants and their wayward wives frequently appeared in the pages of Giornale di Sicilia, the island's largest newspaper, testifying to the dangers inherent in transoceanic migration. These stories of betrayal, adultery, dishonor, and infanticide in the popular press symbolized the fears of social disintegration that prominently figured in political debates surrounding mass male emigration.

The idea that migration would destroy the family, the social fabric of south Italy, was extraordinarily powerful in Italy at the beginning of the early twentieth century. Italian politicians and social critics based their belief on the assumption that by separating sexually-active married men and women, migration would unleash the destructive power of sex. The absence of men would transform women into prostitutes and men into bigamists. In I9IO, the prefect of Cosenza, a city in Calabria, reported, "[ $\mathrm{t}]$ oday we are confronted with prostitution among a class of women who formerly, in spite of their poverty were respectable. Then, too, infanticide

8. Giornale di Sicilia, "Cronaca siciliana: I drammi dell'adulterio", (4-5 February 1908), p. 5. 
is rapidly making itself felt - an evil unknown here a few years ago". ${ }^{9}$ Four years earlier, Augusto Bosco, writing in the Giornale di Economisti, described how migration loosened family bonds, and that "this dissolution of the family (whose solidity is one of the strengths of the South) causes economic, as well as moral and judicial damage". ${ }^{\text {IO }}$ Even if wives agreed to take the children and follow their husbands overseas, the "nuclear family suffer[ed] a most horrendous blow". ${ }^{I 1}$ These politicians believed that the moral, ethical, and cultural codes supporting the family disintegrated in the face of American ways: more than one "husband finds himself with two wives, or with his wife and lover living under the same roof, with children born indifferently from one and the other". ${ }^{12}$

Popular literature played on these same themes of moral degeneration and abandonment, reinforcing the fusion of emigration with familial disintegration. In Luigi Pirandello's story L'Altro Figlio, first published in I923, the townswomen sit outside their doorways, cleaning beans, knitting and mending, and, like a chorus in a Greek tragedy, they list the latest families to fall victim to male emigration.

\footnotetext{
"Saro Scoma, departed" - said one - "He left a wife and three children". Another joined in, "Vito Scordia left five (children) and a pregnant wife". A third asked, "is it true that Carmine Ronca took his twelve-year-old son, who was already working in the sulphur mines with him? Oh, Santa Maria, he could have at least left the boy with his wife. Now who will help her, la povera cristiana?" A fourth loudly lamented, "What crying, what crying all through the night, in Nunzia Ligraci's house! Her son Nico, who just returned from the military, wants to emigrate". ${ }^{13}$
}

In these laments, the exodus of men is the equivalent of social death for the women and children left behind.

Once abandoned by their men, these fictional heroines went insane or died. In La 'Mèrica, first published in I9ıо, Catena, diagnosed with trachoma, is unable to accompany her husband. Desperate to join him, she seeks assistance from the local pharmacist. The prescribed poultices leave her blind. Left behind, her family destroyed, she goes crazy. ${ }^{\mathrm{I}} \mathrm{Gli}$ Americani del Rabbato, by Luigi Capuana, published in I9I 8, opens to the screams of a woman echoing through the streets. When a neighbor rushes to the window to see what happened she is told that la scarsa (the halfwit)

9. US Senate Reports of the Immigration Commission, Emigration Conditions in Europe, SixtyFirst Congress, Third Session, S. Doc. 748, (Washington DC, I91 I), p. 227.

ı०. Augusto Bosco, "L'emigrazione dal mezzogiorno", Giornale degli Economisti, 32 (1906), pp. $313-330,324$.

I I. Giuseppe Bruccoleri, L'emigrazione siciliana: caratteri ed effetti secondo le più recenti inchieste (Rome, I9I I), p. 6.

I2. Ibid., p. 6.

I3. Luigi Pirandello, Novelle per un anno (Verona, 1964), p. 927.

I4. Maria Messina, "La Mèrica," Piccoli gorghi (I9I I; repr. Palermo, I988), pp. I27-I37. 
just received news that her husband had taken another wife in la 'merica. ${ }^{\text {is }}$ In Nonna Lida, a short story by Maria Messina, an elderly woman is found frozen to death in a field outside town, the day after she sends her grandson off to America to join her only son. ${ }^{16}$ In popular literature, the destruction of the family that accompanied the departure of each husband or son was embodied in a woman's physical suffering.

Alongside the common image of these pitiful wives and mothers abandoned by their men, appeared that of the man destroyed by the sexual exploits of his wife. According to Charlotte Gower Chapman, a song popular in the r 930 s told how

The wives of the Americans [a term applied to migrants]

Eat and drink like dogs.

They go to the church and pray to God:

"Send me money, my husband.

For if you do not send me money, I will change your name

And Christen you Pasquale" [a name which implies cuckold]. ${ }^{17}$

The anthropologist, Vito Teti, found a number of Calabrian folksongs during the first decades of the twentieth century echoed these sentiments. In these songs, the greed and sexual voracity of the Americane, as the wives of absent migrants were sometimes called, destroyed the family their husbands left behind. While these men struggled to save a few hundred lire, their wives back home demanded ever more money as they reveled in their freedom, sleeping with the first man to come along. In the words of one popular song, "Send me money, my husband/ I'll take care of the horns". If husbands returned home to find one or two more children at the table, it was only to be expected. In popular myth, America turned men into cuckolds, women into prostitutes and families into ruins. ${ }^{18}$

Patterns of migration fueled fears expressed in story and song. The demographics of Sicilian emigration suggested that men were leaving their women behind in rapidly growing numbers. Between I876 and I9I5, 73 per cent of all migrants who left the island were adult men. During the peak years of migration, after I90I, most emigrants traveled alone. ${ }^{19}$ The marital status of migrants is difficult to glean from published government statistics. However, family reconstructions culled from birth and marriage records, combined with ship manifests and passport records, show the typical migrant to be married, between the ages of twenty-three and forty-

15. Luigi Capuana, Gli Americani di Rabbato: Racconto (Palermo, I918), p. I7I.

I6. Maria Messina, "Nonna Lida", Piccoli gorghi, p. I47.

17. Charlotte Gower Chapman, Milocca: A Sicilian Village (Cambridge, MA, 1971), p. 108.

I8. Vito Teti, "Sui comportamenti delle donne sole degli 'americani' durante la prima emigrazione in Calabria”, Studi Emigrazione, 85 (1987), pp. 13-46, 20-27.

19. MAE, Annuario, pp. I83, I93, 204. 
five, traveling with his brothers or other male relatives. ${ }^{20}$ The numbers show that men migrated and women stayed home. This gendered experience of migration had a particular meaning in a culture where social relations were shaped by a code of honor that demanded constant male supervision of all female family members.

Rural Sicilians measured a man's honor, and by extension that of the family, by his ability to control female sexuality. In this society where honor was a tangible resource - the basis for negotiating work contracts, building a clientele and negotiating marriages - an unprotected woman posed a clear danger to the entire kin network. Quickly, the wife of a migrant, like a widow, could easily become the subject of rumors and innuendoes. As one proverb held, "A match held close to the fire will eventually light." ${ }^{21}$ Whether or not a woman entered into a physical relationship with another man was, in many ways, less important than what was said about her. Gossip alone could destroy her reputation. The loss of a woman's honor could destroy a family's ability to claim respect and power. Studies, such as Francesco Colletti's I9I 2 report on Italian emigration, showing falling rates of illegitimate births in areas of high migration, proved these arguments to be false. In Calabria, a region that had higher rates of male emigration than Sicily, the number of illegitimate or exposed children fell from 805 per 10,000 live births in I 890 to 462 in I909. Lorenzoni's study of rural Sicily showed that the number of illegitimate births fell from 3.4 per cent to 2.7 per cent between 1903 and 1907..$^{22}$ Despite the statistical evidence contradicting popular belief, the idea that unsupervised women posed a threat to the community had real consequences for Sicilian women and their families.

On occasion, these swirling rumors of sexual licentiousness and adultery ended in tragedy. This was the case for Graziella Li Giovanni who, early one July morning in I9I3, dressed in her Sunday best as if to go to mass, went into her bedroom, shot and killed herself. A year earlier, she had married a man from Milocca in accordance with her parents' wishes. Within a few months, the couple's fighting had led to separation, and her husband left for America. She returned to live in her father's house in Racalmuto, but the gossipmongers would not "save her honor". Unable to

20. This information is derived from a migrant file I created, based on information contained in birth and marriage records and passport lists from the communal archive in Sutera, Caltanissetta, combined with passenger lists of ships arriving in New York City harbor. The file contains information on 7I4 migrants from Sutera.

21. Chapman, Milocca, p. 40. Donna Gabaccia, From Sicily to Elizabeth Street: Housing and Social Change Among Italian Immigrants, I880-I930 (Albany, NY, I984), p. 9.

22. Francesco Colletti, Dell'emigrazione italiana (Milano, I9I2), pp. 230-23I; Giovanni Lorenzoni, Inchiesta parlamentare sulle condizioni dei contadini nelle province meridionali e nella Sicilia, 6, Sicilia, book I, part 3 (Rome, I910), p. 467. 
bear the innuendoes questioning her conduct and honor, she chose death. ${ }^{23}$ In other instances, women died from their efforts to conceal evidence of sexual misconduct. Giovannina Salvaggio died in prison from medical complications after she had been convicted of having an abortion "to escape the dishonor and anger of her husband, who was already on the road home". The stories of Graziella and Giovannina bear witness to the tragic price some women paid for male emigration. For these women, transatlantic migration truly did destroy their families.

The underlying assumption in these widely circulated tales of tragedy and loss was that transnational migration could easily leave families in ruins. In the popular imagination, the women left behind symbolized the potential danger male emigration posed to family honor. By undermining male authority and privilege, the physical absence of men would loosen family ties and destroy moral order. Although these stories did not reflect the lived experience of most people, they are significant in that they located concerns about the social impact of male emigration in the family, and specifically, in female sexuality. The concentration on the most sensationalized examples of the impact of migration on the family meant that cultural critics, journalists, and politicians failed to see how these stories of sexual betrayal were linked to transformations in men's and women's economic and social roles that strained family relations.

\section{CONFLICTING INTERESTS}

By framing the public debate about the effect of migration on the family in terms of uncontrolled sex, these popular stories and political debates located the source of familial conflict in physical separation, not in the act of migration itself. A closer look at the experiences of men and women from Sicily reveals a more complicated story. The Sicilian code of honor certainly informed the collective identity of men and women, defining gender relations and behavior; but the limits placed on female behavior in public did not translate into powerlessness. Rural women participated in family matters.

The degree of female involvement in familial decisions is reflected in the kinds of tensions that accompanied the decision to emigrate to North America. Even before men set sail for new lands, migration caused conflict between husbands and wives. The decision-making process underlying migration highlighted the differences that defined the familial roles of men and women. For Sicilians, migration was not motivated by a sense of individual gain or adventure: it was a decision made by all family members, a sacrifice undertaken for the good of the family. Both migrating men and

23. "Stoico suicidio a Racalmuto: Abbandonata dal marito e colpita nell'onore", Giornale di Sicilia (22-23 July 1913), p. 2. 
their families were aware that transatlantic migration entailed great risks and many difficulties. Emigrants were not blind to the hardships in America: while they recognized the possibility of acquiring riches, they knew they had to pay a price. As a resident in the district of Corleone said, America was a place where "Sicilians went to earn [money] and often lost their lives". ${ }^{24}$ Migrants were well aware of the additional difficulties and responsibilities shouldered by family members who stayed at home. Most Sicilians decided that the costs outweighed the benefits. Others decided that the high wages in the Americas offset any short-term economic and psychological hardships. Emigration was part of a larger family survival strategy, undertaken to accomplish specific goals. And in most cases migrants and their families believed that separation would not destroy their families. With the money the emigrant sent home, family members paid off any outstanding debts, and then set out to build or buy a larger house. The rest of the money was invested in land. Property ownership brought honor and respect, turning braccianti (day laborers) and mezzadri (sharecroppers) into signori.

Husbands and wives jointly decided who should leave, when they should travel and where they should go. Official female support is visible in the passport records. According to the I90I emigration law, male applicants for an Italian passport had to prove they were not abandoning their dependents to fend for themselves. By 1905 , legislative reform effectively excluded women from the official record. The new law stipulated that a wife's consent was no longer required to request a passport, although every woman retained the right to oppose her husband's application. ${ }^{25}$ While these records offer some evidence that women were more amenable to sending their husbands overseas than popular fiction or political discussions maintained, they cannot tell us how often a man coerced his wife to approve. Clearly passport applications alone are insufficient to make a claim that rural women actively supported their husbands' decision to leave. This official consent takes on greater significance when seen in light of the other ways women participated in the decision-making process underlying mass migration.

The importance of the family becomes more visible in looking at the organization and financing of migrant groups. In Sicily, where men traditionally turned their earnings over to their wives or mothers, raising money for a steamship ticket required a woman's consent and participation. Women had the responsibility for managing the household finances and making daily purchases. Husbands and wives jointly decided on major expenses (property, mules, etc.). To finance one man's trip to America, a

24. Lorenzoni, Inchiesta, part 3, p. 362.

25. MAE, Norme legislative e regolamentari concernanti la concessione di passaporti per l'estero (Rome, I905), p. 25. 
family needed to raise nearly 200 lire (\$50), almost half of a man's annual earnings. ${ }^{26}$ Saving enough money for the voyage would have been difficult without a wife's or a mother's cooperation. Along with raising money for the trip, women also helped organize the journey. Passenger lists from steamships docking at Ellis Island, combined with family reconstructions, show that mothers, wives, and sisters linked seemingly unrelated male migrants. These female networks were a valuable resource for migrants. The evidence that women participated in the decision-making process underlying male emigration suggests that when women supported the idea of migration they invested their own dreams of upward familial mobility into transnational migration, and worked hard to see that they would be realized. However, when women objected to emigration, they had the ability to create insurmountable obstacles.

The ability of women to facilitate or hinder male migration could easily create tensions between husbands and wives, or parents and children. In some families, wives resisted their husbands' plans to emigrate. Women tried to stop male family members from leaving through financial pressure, and even appealed to the authorities. In the town of Solarino in I905, a young man murdered his aunt and benefactress when she refused to give him money to emigrate. ${ }^{27}$ In the fall of 1920 , Francesca G, from Sutera, appeared at the police headquarters in Palermo, demanding that they stop her husband, Ignazio, from sailing to North America. Although it is unclear whether or not she was successful, her action suggests that women believed they had the right to stop their husbands from emigrating. Other women encouraged and even pressured their husbands to leave. Residents of Milocca recounted to Charlotte Gower Chapman how Zia Maricchia drove "her husband to emigrate to America by her unwifely behavior. She had among other things refused to eat of the same dish with him, and insisted on having her own drinking glass at meals". Her refusal to accommodate her husband, it is implied, extended into the bedroom, with perhaps more effectiveness. ${ }^{28}$

These women who encouraged their husbands to work overseas saw the possibility of earning higher wages in the Americas as a means to better their family's social and economic condition. They invested their own dreams in the migration project and had a great deal at stake in its success. Wives needed their husbands to come back, dressed in the latest American fashions, with pockets full of cash to justify their decision to stay home. If migration could transform their men into entrepreneurs or landowners, it would also transform their lives. The family's improved condition would

26. Lorenzoni, Inchiesta, part 3, pp. 2 I, 34-35, I 36. On average, day laborers could work between I 50 and 200 days out of each year in the interior regions of the island. A day laborer could average r.9 lire a day hoeing, sowing and plowing, and slightly more during the harvest. 27. Ibid., part 4, p. 690.

28. Chapman, Milocca, p. Io9. 
ensure that women could arrange better marriages for their children, and build or buy larger houses. Women, like their men, could hope to better their own social position within the village. While men and women shared the original goals underlying mass migration, and did not see it as a permanent separation or as the precursor to uprooting the family, the experience of migration often changed these initial dreams, creating conflict across the Atlantic.

When the men left their island homes, they believed that they were going to a land where they could work hard to earn enough money to come home and live as a respected landowner. What they found overseas often radically transformed this understanding of the purpose of migration. In America, migrants were able to find work that paid seven to thirteen lire a day. In Sicily the average daily wage for agricultural workers ran between one and two lire per day. ${ }^{29}$ After finding steady work and higher salaries, it was sometimes difficult to contemplate a return to rural Sicily. Emigrants also justified their decision to stay and raise their children in America by pointing to the better opportunities for upward mobility. In America "they [the children] can get an education and become something. Al paesello nostro, non c'e nulla. In our little town there is nothing, so we must remain here for their sakes". $3^{\circ}$ The combination of work and a society far removed from their semifeudal homeland, led many migrants to decide to remain in the United States and send for their families. In the United States one lived "much better" than in Italy. It was a better place for a working man. ${ }^{3}$

The decision of these male migrants to stay in America betrayed the original goals the family agreed upon when they first decided to send someone overseas to work. Women did not experience the same tension between familial duties and personal desire as men. After years of sacrifice and struggle, they often saw little reason to uproot their families and move overseas, and had little sympathy with their husbands' desires to settle in America. When Carmela S supported her husband's application to emigrate, she did so "in the hope that he will find work and send his savings back to his family". ${ }^{32}$ Like Giuseppa T, she never envisioned that migration would force her to leave Sutera. The ever-widening chasm separating migrants' aspirations from those of their wives back home caused deep rifts within the family. One man recounted "I returned to get my family but they do not want to come, so I will return to America

29. Lorenzoni, Inchiesta, part I, pp. 73-86, and part 3, p. 268.

30. Antonio Mangano, “The Effect of Emigration Upon Italy: 'Ci manca la mano d'opera' 'We lack the working hand'”, Charities and The Commons, 20 (4 April i908), pp. I3-25, 24.

3. Ibid., p. 25; Lorenzoni, Inchiesta, part 3, p. 273.

32. ACS, "Domanda di nulla osta-Giuseppe C., I90 I", cat. I 3, cl. 3. 
alone". ${ }^{33}$ Other men chose to abandon their plans to re-emigrate. In any case, a struggle commonly ensued that broke families apart, forced women to uproot their children, or, caused men to relinquish their dreams of settling in the United States.

\section{A CHANGING FAMILY ECONOMY}

The experience of migration did not change the original goals of all migrants. Despite their ability to command higher wages and find work more readily in the Americas, over half of the south Italian emigrants eventually returned to Italy. In Sutera, the repatriation rate reached nearly 70 per cent. ${ }^{34}$ For returnees, their arrival back home marked the end of their journey, and hopefully, validated their original decision to leave. From the moment they left, emigrants dreamed of home. As Giovanni Lorenzoni wrote in the 1907 senate inquiry,

In far away America, amidst the chaos of Cyclopic cities, and factory smoke they dream of the beautiful Sicilian sun. They dream of the sea perpetually hugging the land, the hills and fields where their children run, the sound of language of their home, the poetic summer nights, their women's kisses, and as soon as they can, they leave: but they want to return victorious, not defeated. ${ }^{35}$

Generally, the men returned as soon as they had saved enough money to build a new house and to buy a small piece of land, as soon as they could return "victorious".

For these men, family continued to frame their migrant experience. Many of the migrants interviewed by the members of the I9Io government inquiry returned because their wives, children, fathers, or mothers needed them. One man from the province of Siracusa declared, "I returned, not because I lacked work, but because here I had my wife and children, who are my real property and my only treasure"..$^{36}$ Not only did they make the decision to return home in the context of the family, they also measured the success of their time in the Americas by their improved ability to provide for their families. These men spoke proudly of how America made them better providers, literally transforming them into breadwinners. "I

33. Lorenzoni, Inchiesta, p. 279.

34. US Senate Reports of the Immigration Commission, Emigration Conditions in Europe, Sixty-First Congress, Third Session, S. Doc. 748, (Washington DC, I91 I), p. 228; International Migrations: Statistics, (New York, I929), pp. 454 and 477; Alberto Beneduce, "Sul movimento dei rimpatriati dalle americhe", Giornale degli Economisti, 3 (г910), p. 240. Betty Boyd-Caroli, Italian Repatriation from the United States, 1900-1914 (New York, 1973), p. 9. Local information is culled from the migrant file from Sutera.

35. Lorenzoni, Inchiesta, part 5, p. 755.

36. Ibid., part 3, p. 381. For a discussion of how migrants used remittances see part 5, pp. $382-383$. 
went to America and now my children, who before could hardly nourish themselves with corn can now enjoy good bread." 37 Their families lived and ate better as a consequence of migration. For these men, transoceanic migration fulfilled its promise of improving their family's condition back home, and at the same time transformed their position in the family. Their experience as migrant laborers in a global capitalist economy emphasized the importance of being a provider in defining their roles as fathers, husbands, and sons within the family. Increasingly, wages defined a man's importance, not the size of his family or how much land he owned. These new definitions of husband, worker, and father that male migrants brought home to Sicily often led to familial conflict.

In many families where migration fulfilled its promise, new tensions surfaced a few months or a year after the men returned. After the euphoria of coming home to their wives and children with a few thousand lire in their pockets had worn off, migrants had to face the difficulties of daily life. Migration had not improved employment opportunities at home, and migrant remittances inflated land prices, and the cost of living. Their hard-earned savings frequently fell short of moving their families up the social ladder. Male migrants were acutely aware that the antiquated social hierarchy compounded the economic obstacles in climbing the social ladder. In the words of one man,

[...] when I returned from America, I bought a house and a mule: but here one cannot even grow grass. Salaries that two years ago were two lire have fallen, because of the returning migrants, to one and a half lire. The signori have the land and do not want to give it up; because of this we have to leave our walls and our children..$^{8}$

Another returnee chimed in, "for the inhumane way that the signori treat us, it would be better to put them all in front of the mouth of a canon, except for the Church (not the priests) and the Saints". ${ }^{39}$ Disgusted by the personal disrespect they had to endure, combined with political corruption, falling wages, and the hardships of daily life, migrants began to make plans to return overseas. Their experiences of life in America and in Sicily, upon their return, transformed the meaning of migration for these men. One man from the province of Agrigento stated,

In America, I earned 75 dollars a month as a worker in a sugar factory. They wanted to give me American citizenship, but I did not accept out of the great love I have for this land where I was born. Because of this love and the affection of my family I returned: but I predict that I will not be able to remain, because here the land cannot support us..$^{\circ}$ 
No longer merely a means to improve their family's lives, migration became a vehicle for articulating their growing discontent with the social relations on the island. If the situation did not radically change, if the landowners did not break up their estates, some residents predicted a mass exodus that would leave "the gentry without workers and the state without soldiers". ${ }^{\mathrm{I}}$ Migration transformed the meaning of being a worker for these men. Wage-work no longer required a man's unquestioned acceptance of an oppressive social hierarchy. These men could always sell their labor overseas. Disgruntlement with the economic and social order among returnees created conflicts between migrants' personal ambitions as workers and men and their sense of obligation to their families.

The conflicts that arose between husbands and wives were also a consequence of the effect transnational migration had on women's economic roles. The peak years of Sicilian migration marked a transformation in the rural family economy first visible at the end of the nineteenth century. Between I 880 and I920, rural households became more dependent on wages and consumer goods. By the I920s, most households bought their clothing and a good portion of their food. While gardens provided a family with vegetables, people purchased pasta and bread, the mainstay of the diet. Throughout the early twentieth century, the rural Sicilian family economy remained rigidly divided by gender, although the kinds of work men and women did changed. Men continued to work in the fields, but more and more of them worked as day laborers than sharecroppers. ${ }^{42}$ Women remained in the villages. Unlike on the mainland or in northern Europe, Sicilian women rarely worked the land. The history of land tenure on the island placed vast tracts of land in the hands of a few, leaving little room for small family farms. The fields on the large latifundia were located far from towns. The dangers inherent to the countryside roving bands of brigands and the pervasive presence of malaria in the lowlands - posed physical dangers to rural Sicilians, discouraging them from settling with their families far from the safety of the hill towns. ${ }^{43}$ While men worked in the fields from Monday to Saturday, the women made the family's clothes, raised the children, and cooked. At the beginning of the twentieth century, however, fewer women made their family's clothes. Increasingly, women purchased dresses and shirts, and furniture. The shift can be seen in the census records that show the falling numbers of women listed as weavers, or engaged in any paid work.

4I. Ibid., p. 316.

42. For household diets and budgets see Lorenzoni, Inchiesta, part 4, p. 460 and Ettore Taddei and Constantino Ledda, Contadini Siciliani, 4, Monografie di Famiglie Agricole (Rome, 1933). For labor patterns, see Donna Gabaccia, Italy's Many Diasporas (Seattle, WA, 2000), p. 6I.

43. Donna Gabaccia, From Sicily to Elizabeth Street, pp. 37-40; Chapman, Milocca, p. 39. Chapman notes that economic necessity had more influence on gender separation then specific cultural codes. 
Between I88I and I92I, the percentage of women engaged in productive work fell from 38 to 8 per cent. The departure of women from the census was a consequence of northern industrialization that had decimated the island's cottage textile industry. While in the north the booming textile industry transformed female weavers into factory workers, in the south it turned women into housewives. As the number of women listed as employed as weavers, spinners, or seamstresses fell, the number of women listed as "without profession" rose. 44

By I907, a woman was measured by her managerial skills and not by her annual earnings. In his tour of Caltanissetta, Giovanni Lorenzoni described his visit to two families. The first family rented seven salme of land and owned two others outright. Out of eight children, four of them were capable of working the land. The second family owned only one salme of land and was able to rent only two others. Only two of the couple's five children could work in the fields alongside their father. Despite the clear economic inequality, Lorenzoni concluded that the second family was better off then the first one.

In the first family everything was going badly: the house was dirty and miserable, the debts grew each year, and there was dirt everywhere, even on the faces of the people; it screamed of misery: in the second [we saw] the opposite phenomena: a well-ordered house, no debt, very clean and dignified. When I marveled at the extreme diversity of the two situations, my guide responded curtly: "the two women deserve the merit and the fault". 45

By 1907 a woman's ability to manage the household budget translated into familial prosperity. As the ability to consume became as important, if not more important, than land ownership, transnational migration increased the signficance of women's economic roles.

These complementary gender roles within the family economy recognize that rural Sicilian women commanded some degree of power in the family and community. The notion of a cooperative family, however, does not assume that relations between wives and husbands were necessarily harmonious or equal. While married couples probably wanted to provide the best life possible for their children, how they

44. Jole Calapso, "La Donna in Sicilia e in Italia: la realtà e la falsa coscienza nella statistica dal I87I ad oggi", Quaderni Siciliani, 2 (1973): pp. I 3-20; Donna Gabaccia, "In the Shadows of the Periphery: Italian Women in the Nineteenth Century", in Marilyn J. Boxer and Jean H. Quataert (eds), Connecting Spheres: Women in the Western World: I 500 to the Present (New York [etc.], 1987), pp. I66-176. Ministero di Agricoltura, Industria e Commercio [hereafter MAIC], Direzione Generale della Statistica [hereafter DGS), Censimento della popolazione del Regno d'Italia al 3 I dicembre I 88I, vol. 2 (Rome, I 883), pp. 276, 29I, 345, 379, 4 I , 492, 506; and vol. 3 (Rome, I883) pp. 584-593; MAIC, DGS, Censimento della popolazione del regno d'Italia I92 I, I9 (Rome, I927), pp. 238-239; ibid., I I (Rome, 1926), p. 8.

45. Lorenzoni, Inchiesta, part 4, pp. 463-464. 
defined the "best life", and the paths they set out to achieve it, often differed. A male head of household might define his goals in terms of leaving his children a larger inheritance when he died, or selling off land for immediate cash. For his wife, it might mean negotiating good marriages for the children. ${ }^{4}$ It is important to note that these two worlds often came into direct conflict as they competed with each other for a family's scarce resources. What portion of the meager weekly wage should go to a husband's pleasure or into the family's savings? Should the family invest its savings in a mule or in trousseaux for a daughter? Or, increasingly, with the opportunities offered by mass male migration, should the family remain in Sicily or move to the United States?

The economic effect of mass migration on rural Sicilian women sharpened the competitive relationship between wives and husbands. Remittances from overseas encouraged the gradual withdrawal of women from paid labor that began in the last decades of the nineteenth century. Despite causing female wages to rise sharply, male migration had little effect on the disappearance of women from paid labor. It is not surprising that the wives of migrants refused to sell their labor for a weekly wage. If rural women did choose to work in the fields, they undermined the family's ability to improve its material condition. To claim a position of respect in the community, the wives of emigrants had to emulate the lives of the most respectable women in town. A woman who worked alongside the men in the wheat fields seriously harmed the family's ability to position themselves alongside the local elite, no matter how much money her husband earned overseas. ${ }^{47}$ As a consequence of global industrialization and cultural codes defining women's work, transnational male migration did not strengthen female paid labor. Instead, emigration reinforced a gendered division of labor that identified men as the breadwinners and women as the household managers and consumers. As Susan Porter Benson has argued, the construction of "the good manager role" took a toll on women, as new expectations and burdens were placed on their shoulders. ${ }^{8}$ The potential for conflict between women's roles as managers and their husbands' roles as wage-earners increased as the family's discretionary income rose.

Women married to migrants had more money to spend then ever before. Across rural Sicily, the amount of money deposited in rural savings banks and cooperatives rose dramatically between 1907 and 1920. Deposits in postal savings accounts in Sicily rose from $62,304,593$ lire in 1900 to 
I 22,987,0I 4 lire in 1907.49 In their roles as household managers, women spent or saved this money as they saw fit. After they paid off their families' immediate debts, women invested the family's savings in new houses. The land cadastre shows that more than 75 per cent of the wives of migrants, who appear in the property rolls, bought or built a new house between I900 and I920. Often women did not even wait for their husbands to return before they bought a new house or built an addition on to their old one. Nearly a quarter of the women who appear in the cadastre, and whose husbands worked overseas, registered new or renovated houses while their husbands were gone, and women completed 20 per cent of all sales transactions before their husbands came home. ${ }^{50}$

Rural women used remittances to purchase the physical appearance of the bourgeois world. Unlike land, which measured male wealth, houses and consumer goods testified to a woman's improved status. The wives of migrants moved their families into roomy, two-story houses, preferably with small separate kitchens off one room. The average size and the net worth of the buildings owned by these women were twice that of those owned by women whose husbands remained home. As soon as the families moved into their new homes, women began to replace their old furnishings with new, store-bought iron bedsteads, tables and dressers. In purchasing homes and furnishing them with rugs, lamps, and mirrors brought in from Palermo or Agrigento, these women took the initial steps to fulfill the dreams they invested in migration. However, decisions how and where to spend the money often conflicted with their husband's wishes. Houses and land were expensive. By 1907, residents across the island complained of the rising prices of land and consumer goods. By the time the migrant returned home, there was often not enough money left over to realize his goal of buying enough land to live comfortably off the rents, or to even invest in a small business. In that case he was left with two choices. He could reemigrate or return to his earlier life as a sharecropper or day laborer.

While male migration increased a woman's disposable income, enabling her to participate in the expanding world economy as a consumer, it also caused problems within the family. Not only did husbands and wives disagree over how the money should be spent, the transatlantic cash economy also created new difficulties for women in gaining access to the money. Wives rarely had access or direct control over their husbands'

49. Lorenzoni, Inchiesta, part 5, pp. 847-848. Dott. Giovan Battista Raja, Il fenomeno emigratorio siciliano (con speciale riguardo al quinquennio 1902-06) (Palermo, 1908), table n. I 2, table n. I 3 .

50. Archivio dello Stato-Caltanissetta, Catasti dei terreni e Catasti dei fabbricati Sutera I880I940. Women whose husbands remained home did not have the means to invest in real estate. Less than half of these women were able to purchase or build a new house; more often than not, they acquired new property through inheritance. 
wages. While they could spend what they received, they had no way of ensuring their husband sent all the money he earned. Outside social controls imposed by family and kin, women became more dependent on the goodwill of their spouses. The physical distance separating husbands and wives weakened the ability of women to monitor their husbands' earnings.

In a similar fashion, the distance between family members often led to tensions between mothers and sons. In 1938, in the coastal village of Ficarazzi, located near Palermo, an emigrant, resident in the United States, wrote to the mayor requesting that the state stop his mother from lending money. For the last seventeen years, he wrote, he had sent money and clothing home to his widowed mother, fulfilling "his duty as an Italian son". Recently, however, his brother confirmed rumors filtering back to Philadelphia that his mother was selling the clothing and shoes he had given her and was using all the money from her son to lend out at high interest rates. ${ }^{\text {I }}$ In the eyes of the son, his mother warped his filial devotion. The clothes and money were testimony to the dependent relationship that tied widowed women to their sons. In seeking to make the money hers, Giuseppa L not only asserted her independence, she violated family relations. Selling his tokens of love, made with "extreme sacrifice to himself and his family", while at the same time demanding more money to finance her immoral affairs angered her son enough to ask the mayor's office to step in.

The economic effects of mass male migration led to strife between the female consumers and male providers. Entry into the industrial world economy not only changed the structural nature of the family, altering patterns of women's work, but also profoundly transformed the relations between men and women. As transoceanic male migration encouraged the family to assume the form of a consumer-wage economy, competing interests between women as managers/consumers and men as wage earners grew more intense.

\section{CONFLICT AND THE CHANGING ROLES OF HUSBANDS AND WIVES}

Just as migration changed the dynamics of the family economy, it also altered notions of being a husband or wife. On io January I9I6, an emigrant from Campofranco wrote to Don Giuseppe Randazzo, a local priest, complaining that he had heard rumors that his wife was unfaithful, and he asked the priest to castigate her in his absence. He told the priest to let his wife know that he would forgive all of her transgressions if she 
caught the next boat to America, although he categorically refused to return to Sicily and settle in a nearby town, as she had suggested. The cuckolded husband wrote, "She should sell everything and come. If she wants to regain her honor that is the only remedy." 22 The emigrant's response to his wife's infidelity is significant. According to the Sicilian code of honor, there was no place for forgiveness without bloodshed. A man lost respect if he did not quickly avenge his honor through violence. In the United States, however, the sexual relations between husband and wife rarely entered the public sphere. Intimate matters remained relegated to the private world of family, unless they ended in murder. Betrayal and adultery could cost a man a certain amount of individual prestige, but it did not destroy his ability to provide for his family, or create social and economic opportunities for his children.

This new meaning of being a husband filtered back to the island. As a consequence of migration, some Sicilian men turned to the courts to reclaim their honor back home. In March I9I3 the Giornale di Sicilia reported the story of the "peasant", Beniamino Schirò, a young man who had emigrated from the town of Villabate, in the province of Palermo, to Utica in upstate New York. He had left his wife, Isabella Alaimo behind. "[B]elieving that her husband no longer thought of her, and had found another companion, Isabella decided to fill the void with Giuseppe Tesauro, also of Villabate." Beniamino, who assumed his wife had remained faithful, asked her to join him in New York. "The wife had to obey: but she found herself in grave difficulties, being in a condition that from one day to the next her husband would have to recognize that his Isabella had not been faithful.” Isabella, claiming that American air did not suit her, returned to Palermo and her old life. Relatives quickly informed Beniamino that Isabella was "anything but sick". Beniamino charged his brother with bringing a civil suit against his errant wife and Giuseppe. On the morning of I4 March, the two lovers where arrested and sent to prison. 53 This story provides some indication of how migration changed notions of masculinity and honor. The family could publicly reclaim their respect through legal methods. What makes the case even more interesting is that a few days later the paper printed a correction, noting that Beniamino Schirò was not a "peasant, as had been erroneously reported". And, "that he had emigrated to America in 1909, and opened a business in Utica (and in only three years had sent his wife, who did not need assistance, 3,525.I 5 lire). One cannot say, therefore, that Signore Schirò neglected his wife." For Beniamino, and his fellow emigrant from

52. Cataldo Naro, Momenti e figure della chiesa nissena dell'otto e novecento (Caltanissetta, 1989), p. 535 .

53. "Cronaca di Palermo: Arresto per adulterio", Giornale di Sicilia (13-I4 March I9I3), p. 5. 
Campofranco, being a husband was tied more to their private role as providers, than their public roles as protectors of female sexuality.

Just as emigration offered new familial role models for men, it also changed the meaning of marriage and family for women. Being a wife no longer meant being the repository of family honor, although women continued to be judged by their sexual activities. The exigencies of migration encouraged women to take on new duties as public representatives of the family. The struggles that marked the economic transformation of rural life accompanied a political transformation, as the exigencies of migration pushed motherhood into public spaces. Throughout Sicily, women used local government and consulate agencies to pressure their distant husbands to fulfill their familial obligations. In 1937, Caterina M appealed to the Mayor of Ficarazzi, to help locate her husband, Domenico $\mathrm{L}$, in Brooklyn. She had not heard from him in over three years and had been forced to sell the "little she owned", and was now deeply in debt. The mayor urged the consulate to find Domenico and "urge him to respect his conjugal duties [and to send] the money necessary to make his wife's economic situation normal again". ${ }^{4} 4$ In their efforts to continue to exercise their traditional roles as household managers, women turned to the state for assistance and justice. The state strengthened the ability of rural Sicilian women to define the meaning of migration for themselves and their families. Their emergence into the public sphere as mothers and wives gave women the moral authority to refuse to join their husbands overseas. A wife did not have to obey her husband, if his demands seemed to undermine the family's wellbeing.

In the lives of Giusppa and Carmelo, Domenico and Caterina, and the other men and women who provided the stories for this essay, the family does not appear as a united body. Complicated bonds, made up of a mixture of blood, love, obligation, dissension, competition, accommodation, and compromise, tie individuals together. The delicate balance that holds these competing forces together is under constant negotiation, and reflects the deeply gendered nature of European society. The communities men and women live and work in also inform familial relations. When these worlds change, so does the meaning of husband, wife, father, mother, daughter and son. The family does not just adapt to the exigencies of new political borders, industrialization, and the expansion of global capitalism. It also transforms the meaning of male and female in these new worlds. The transnational family, where production, reproduction and consumption are physically separated, highlights the central role the rural family played in reordering notions of gender in early twentieth-century Italy.

54. ACF, “Memo: Dal Consolato Generale d'Italia al Podestà, 22 Novembre 1937”, cat. I, cl. 3. fasc. I. Doc\# I 836 . 